\title{
STATUS OF DISCHARGED ABATTOIR EFFLUENT AND ITS EFFECTS ON THE PHYSICO-CHEMICAL CHARACTERISTICS OF OROGODO RIVER, DELTA STATE, NIGERIA
}

\author{
GODWIN ASIBOR, OGHENEKOHWIRORO EDJERE \& CHRISTOPHER AZUBUIKE \\ Department of Environmental Management and Toxicology, Federal University of Petroleum Resources, Nigeria
}

\begin{abstract}
The discharge of untreated wastewater into waterbodies results in water quality deterioration of the receiving waters. This study assesses the impact of abattoir wastewater discharge on the water quality of the Orogodo River in Nigeria. Effluent discharges and water samples were collected from the river at six points over a 6 -month period. Physicochemical analyses were conducted using standard methods. The $\mathrm{pH}$ was within a fixed band of 5.56-8.04. The downstream biochemical oxygen demand of the receiving river water increased significantly to $75 \%$ in July and up to $192 \%$ in December. Suspended solids, chemical oxygen demand, total nitrogen and total phosphorus followed a similar trend. Dissolved solids, dissolved oxygen and nitrate also increased appreciably. The downstream levels of these parameters were higher than their corresponding upstream values, indicating that the discharge of the abattoir wastewater into the river has negatively impacted the river water. The dilution of the waste in the river water was not enough to reduce them to acceptable levels. This study demonstrates that abattoir wastewater impacts Orogodo River water negatively. The abattoir effluent did not meet the National standard for effluent discharge into the environment leading to cross pollution of the receiving water based on the parameters investigated. This, therefore, calls for the need to put an effective wastewater treatment and monitoring system in place to enforce existing legislations to curb water pollution and to safeguard both the environment and human health.
\end{abstract}

Keywords: abattoir, wastewater, physico-chemical, impact, Orogodo, pollution, effluent, parameters, discharge.

\section{INTRODUCTION}

An abattoir is a facility approved and registered by the controlling authority for hygienic slaughtering and inspection of animals, processing and effective preservation and storage of meat products for human consumption [1]. The abattoir industry provides domestic meat supply to over 150 million people and employment opportunities for the Nigerian teaming population [2]. Discharge wastes from abattoir can be valuable for crops as fertilizers but can becomes a major pollutant when the wastes are not properly managed [3].

According to Mittal [4] and Adeyemi-Ale [5] waste generated at abattoirs pose a serious threat to the environment because of direct discharges of wastewaters into the ecosystems which most times are not effectively treated. These wastes are high in organics and fats [6]. These result to the destruction of primary producers in the water. It is one of greatest threats to surface water quality as it causes an increase in the biochemical oxygen demand (BOD), chemical oxygen demand (COD), total solids (TS), $\mathrm{pH}$, temperature, turbidity, nitrate, phosphate, etc. [7]-[15]. Biodegradable organic matter in receiving waters create high competition for oxygen within the ecosystem leading to high levels of BOD and a reduction in dissolved oxygen (DO), which is detrimental to aquatic life and affects sediments and surrounding soil.

In a typical Nigerian abattoir, the surrounding land is often marshy due to improper channelling of wastewater arising from the dressing of the slaughtered animals and washings 
at the lairage [3]. Most Nigerian abattoirs are situated close to surface water bodies in order to have access to cheap water supply needed for slaughtered animal processing and to provide a sink for the run-off from meat processing activities [10], [16].

In Nigeria, like in many other developing countries, discharge of untreated wastes into the environment is a major environmental issue. Compromised water quality and poor sanitary conditions of abattoirs in the livestock sector have added in no small way to the lotic water system [17].

The two studied abattoirs are located at the bank of Orogodo River in Agbor, Delta State. The Abattoir serves the entire town, and its location beside the stream has facilitated easy disposal of the wastes into the stream channel. Wastes from the abattoir are not treated before discharge into the river. This study therefore examines the implication of the continuous discharge of these untreated abattoir effluents on the river water quality. This is seen to be justified by the fact that the downstream residents very much depend on the water for most of their domestic and commercial activities. This study therefore evaluates the water quality downstream of the river, with the aim of establishing the extent to which untreated abattoir wastes would have impacted on the stream water quality and the point at which appreciable self-purification is attained.

\section{MATERIALS AND METHODS}

\subsection{Study area}

Orogodo River lies within the humid tropical zone with defined dry season (November-March) and rainy season (April-October). The rainy season is brought about by the South-West Trade Wind blowing across the Atlantic Ocean, while the dry, dusty, and often cold North-East Trade Wind blowing across the Sahara Desert dominates the dry season with a short spell of harmattan. The relative humidity of the area is high and increases from $70 \%$ in January to $80 \%$ in July. The average atmospheric temperature of the area is about $25.5^{\circ} \mathrm{C}$ in the rainy season and about $30^{\circ} \mathrm{C}$ in the dry season.

Orogodo River is located between latitudes $5^{\circ} 43^{\prime} \mathrm{N}$ and $5^{\circ} 30^{\prime} \mathrm{N}$ and longitudes $6^{\circ} 20^{\prime} \mathrm{E}$ and $6^{\circ} 12^{\prime} \mathrm{E}$ and takes its source from Mbiri village at an elevation of $150 \mathrm{~m}$ above sea level. The river serves as a major source of water for drinking, bathing, fishing, washing, and recreation for the people of Agbor and Owa communities in Delta State, Nigeria. The Agbor and Owa communities, through which the Orogodo River traverses, are mainly peasant farmers whose products include food stuff such as yams, corn, vegetables, cassava, plantain and fruits. Agricultural activities in the area are mostly carried out along the bank of the Orogodo River. Although Agbor and Owa may not be described as industrial communities, there exist pockets of industries (paint and foam industries) as well as many educational institutions whose wastes also find their way into the river [18]. Some physico-chemical characteristics of Orogodo River have been reported. There are two major abattoirs located along the River. The sitting of abattoir is in such a way that the effluent from their operations is discharged directly into the river where any form of treatment.

\subsection{Field sampling and quality assurance}

Samples were collected from six locations along Orogodo River representing the upstream, midstream and downstream of the river after the effluent outfall from the abattoir between the months of June 2016 to March 2017 using the grab sampling methods. The samples represented conditions before discharge, after discharge and further down the river with 
emphasis on mixing of river with abattoir effluent. Details of sample collection are captured in Table 1, while GPS readings for the sampling sites were taken and used to geo-reference the location of the sampling sites.

The physical parameters analyzed include: electrical conductivity (EC), salinity, turbidity, total dissolve solid, alkalinity, temperature and $\mathrm{pH}$. The chemical parameters analyzed include: nitrate, chloride, sulphate, iron, phosphate, chemical oxygen demand (COD), biological oxygen demand (BOD), and dissolved oxygen (DO). The bacteriological parameters analyzed are total coliform and faecal coliform. A total number of sixty water samples were collected along the river channel during the seven-month sampling period. Samples were collected in plastic bottles, pre-cleaned by washing with non-ionic detergents, rinsed with deionized water prior to usage. Samples for BOD and COD analysis were collected in BOD bottles and plastic bottles and covered with aluminum foil. The sample bottles were labelled according to sampling sites. All samples were preserved at $4^{\circ} \mathrm{C}$ and transported to Federal University of Petroleum Resources Effurun (FUPRE) Environmental Management and Toxicology (EMT) laboratory for analyses within 24 hours. The following parameters were determined in-situ: conductivity (EC), temperature, colour, odour, $\mathrm{pH}$, turbidity and dissolved oxygen (DO) using the respective calibrated in-situ kits and meters.

\subsection{Laboratory water analysis}

The chemical oxygen demand (COD), nitrate $\left(\mathrm{NO}_{-3}\right)$, phosphate $\left(\mathrm{PO}_{4}{ }^{-3}\right)$, and sulfate $\left(\mathrm{SO}_{4}{ }^{-2}\right)$ were measured using spectrophotometer. Biochemical oxygen demand $\left(\mathrm{BOD}_{5}\right)$, total dissolved solids (TDS), total suspended solids (TSS), chloride (Cl-), bicarbonate (HCO3-), calcium, magnesium, sodium and potassium were determined using the standard methods [19], [20].

\subsection{Bacteriological assessment of water and effluent samples}

About $100 \mathrm{ml}$ of the water sample was filtered through a filter that retains bacteria. The filtrate was then transferred to petri dishes containing MacConkey agar and incubated at $37^{\circ} \mathrm{C}$ for 48 hours as described by Padilla-Gasca et al. [21]. The numbers of coliform colonies formed were counted using a microscope and the values expressed as $\mathrm{cfu} / \mathrm{ml}$.

\subsection{Data analysis}

The data were analyzed with Microsoft Office Excel and SPSS software version 16.0.

Table 1: Sampling coordinates along Orogodo River.

\begin{tabular}{|c|c|c|c|c|}
\hline \multirow{2}{*}{ Station } & \multirow{2}{*}{ Location name } & \multicolumn{2}{|c|}{ Coordinates } & \multirow{2}{*}{ Status } \\
\hline & & Northings & Eastings & \\
\hline Station 1 & Mr. Biggs & $06^{\circ} 16^{\prime} 20^{\prime \prime}$ & $006^{\circ} 11^{\prime} 16^{\prime \prime}$ & Upstream \\
\hline Station 2 & Aliumeze & $06^{\circ} 16^{\prime} 20^{\prime \prime}$ & $006^{\circ} 11^{\prime} 31^{\prime \prime}$ & Upstream \\
\hline Station 3 & Madam Jacky Slaughter & $06^{\circ} 16^{\prime} 25^{\prime \prime}$ & $006^{\circ} 11^{\prime} 31^{\prime \prime}$ & Discharge \\
\hline Station 4 & MC Commander Slaughter & $06^{\circ} 15^{\prime} 25^{\prime \prime}$ & $006^{\circ} 11^{\prime} 20^{\prime \prime}$ & Discharge \\
\hline Station 5 & Iyama-1 & $06^{\circ} 15^{\prime} 13^{\prime \prime}$ & $006^{\circ} 11^{\prime} 16^{\prime \prime}$ & Downstream \\
\hline Station 6 & Iyama-2 & $06^{\circ} 13^{\prime} 46^{\prime \prime}$ & $006^{\circ} 10^{\prime} 44^{\prime \prime}$ & Downstream \\
\hline
\end{tabular}




\section{RESULTS AND DISCUSSION}

\subsection{Abattoir effluent}

The colour and odour were objectionable; an indication of from the direct dumping of raw blood, fresh and decaying flesh as well as dung from the abattoir into the receiving river without any form of treatment. The untreated abattoir wastewater temperature was slightly warm, ranging from 30.5 to $33.3^{\circ} \mathrm{C}$. Temperature is one of the most important factors influencing chemical and biological characteristics of water. The high temperatures recorded in the untreated abattoir wastewater aids in quick bacteria activities of the products and also assist in the breakdown of wastes into further constituencies. TSS and turbidity varied from $175-480 \mathrm{mg} / \mathrm{l}$ and $104-218 \mathrm{mg} / \mathrm{l}$ with mean concentrations of $320.4 \pm 34.8 \mathrm{mg} / \mathrm{l}$ and $202.2 \pm 22.5 \mathrm{mg} / \mathrm{l}$. The high concentrations of TSS and turbidity are not surprising as these are products of direct discharges from the abattoirs [9]-[14], [22]. The presence of such high concentration of TSS and turbidity reduces the aesthetic value of the receiving water bodies and reduce DO of the river, while the objectionable colour and odour reduces the aesthetic and potability values of the water.

The $\mathrm{pH}$ varied from slightly acidic to slightly alkaline varying from 6.56 to 7.78 with an overall average of $6.74 \pm 0.54$ throughout the sampling period. Wastewater from abattoir generally tends to be alkaline as a result of a high concentration of organic compounds present which is composed mainly of proteins [21], [23]. A similar result was obtained by [7]-[9], [24]. Conductivity and TDS showed same trend as they were all high in the untreated abattoir wastewater.

DO was low $(<1.00 \mathrm{mg} / \mathrm{l})$ in all the locations sampled. DO is a very important parameter for the survival of aquatic organism and is also used to evaluate the degree of freshness of a river [25]. The low value of DO is as a result of the high nutrients contents from the abattoir waste [1], [24]. The BOD was slightly high varying from $88.5 \mathrm{mg} / 1$ to $158.5 \mathrm{mg} / \mathrm{l}$. The strength of domestic sewage is measured in terms of its BOD level. It determines the amount of dissolved oxygen consumed by aerobic bacteria in the decomposition of organic matter in the sewage. A typical wastewater BOD in Nigeria occurred within a range of $200-500 \mathrm{mg} / \mathrm{l}$ [26]. The COD concentration of the wastewater varied from $775-1175 \mathrm{mg} / \mathrm{l}$. Using [27] classification the wastewater can be categorized to be of slightly high in strength. Both BOD and COD are highly related to DO as well as to each other because the BOD and COD directly affect the amount of DO in the river. DO, BOD and COD are important water quality parameters and are very essential in water quality assessment [28]. They are used to determine whether a water body is polluted or not. The higher the BOD and COD values, the higher the depletion of DO in the receiving water by organic and inorganic pollutants present in the effluents. According to Practi et al. [29], BOD, DO, Chloride, $\mathrm{pH}$ and Nitrate are some of the chemical parameters generally used as indices.

The nutrients parameters were observed to be slightly high in the wastewater as indicated in the overall results of nitrate, phosphate, sulphate and chlorides (Table 2). One other major concern observed from the abattoir wastewater discharge to river channel is the high presence of pathogenic bacteria, though this is not strange. Faecal coliform and total coliform bacteria are used as indicators of bacterial contamination of the rivers. The high bacteria populations recorded reflect the input of microorganisms from both the abattoir wastewater and other sources into the river as there is no toilet facilities for the operators. 
Table 2: Physicochemical and bacteriological results of the Orogodo River and discharged Abattoir effluent.

\begin{tabular}{|l|c|c|c|c|c|c|}
\hline \multicolumn{1}{|c|}{ Parameters } & Station 1 & Station 2 & Station 3 & Station 4 & Station 5 & Station 6 \\
\hline $\mathrm{pH}$ & $5.73 \pm 0.43$ & $6.59 \pm 0.25$ & $6.72 \pm 0.37$ & $6.76 \pm 0.03$ & $5.64 \pm 0.38$ & $5.34 \pm 0.66$ \\
\hline Temp $\left({ }^{\circ} \mathrm{C}\right)$ & $26.72 \pm 2.61$ & $25.26 \pm 2.4$ & $32.5 \pm 0.82$ & $33.3 \pm 0.74$ & $25.26 \pm 2.35$ & $25.5 \pm 2.0$ \\
\hline $\begin{array}{l}\text { Conductivity } \\
(\mu \mathrm{s} / \mathrm{cm})\end{array}$ & $72.8 \pm 6.85$ & $74.54 \pm 3.4$ & $780 \pm 48.3$ & $841 \pm 32.0$ & $85.69 \pm 6.78$ & $74.8 \pm 4.2$ \\
\hline $\mathrm{TDS}(\mathrm{mg} / \mathrm{l})$ & $65 \pm 4.33$ & $69.32 \pm 3.56$ & $677 \pm 52.1$ & $750 \pm 47.1$ & $77.94 \pm 8.45$ & $67.4 \pm 3.2$ \\
\hline $\mathrm{TSS}(\mathrm{mg} / \mathrm{l})$ & $14.6 \pm 4.09$ & $16.47 \pm 3.22$ & $185 \pm 12.7$ & $227.2 \pm 26.5$ & $15.81 \pm 1.19$ & $15.2 \pm 1.88$ \\
\hline $\mathrm{DO}(\mathrm{mg} / \mathrm{l})$ & $2.53 \pm 0.39$ & $3.21 \pm 0.26$ & $0.79 \pm 0.23$ & $0.2 \pm 0.01$ & $3.89 \pm 0.57$ & $4.28 \pm 0.41$ \\
\hline $\mathrm{BOD}(\mathrm{mg} / \mathrm{l})$ & $11.8 \pm 1.89$ & $11.27 \pm 0.79$ & $95 \pm 4.97$ & $112.5 \pm 4.2$ & $7.83 \pm 2.08$ & $6.87 \pm 1.39$ \\
\hline $\mathrm{COD}(\mathrm{mg} / \mathrm{l})$ & $78.6 \pm 3.68$ & $88.7 \pm 4.76$ & $964 \pm 8.43$ & $1045 \pm 42.2$ & $110.2 \pm 14.2$ & $61.1 \pm 10.4$ \\
\hline $\begin{array}{l}\mathrm{Turbidity} \\
(\mathrm{N} . \mathrm{T} . \mathrm{U})\end{array}$ & $26.5 \pm 6.18$ & $22.4 \pm 1.26$ & $108 \pm 4.83$ & $150 \pm 4.71$ & $23.7 \pm 1.2$ & $24.3 \pm 1.53$ \\
\hline $\mathrm{PO}_{4}{ }^{3-}(\mathrm{mg} / \mathrm{l})$ & $0.06 \pm 0.05$ & $0.05 \pm 0.03$ & $5.49 \pm 0.17$ & $10.55 \pm 0.64$ & $0.04 \pm 0.03$ & $0.03 \pm 0.01$ \\
\hline $\mathrm{Cl}^{-}(\mathrm{mg} / \mathrm{l})$ & $0.62 \pm 0.07$ & $3.55 \pm 1.10$ & $46.8 \pm 3.2$ & $49.3 \pm 1.03$ & $0.96 \pm 1.02$ & $0.55 \pm 1.16$ \\
\hline $\mathrm{SO}_{4}{ }^{2-}(\mathrm{mg} / \mathrm{l})$ & $1.94 \pm 1.23$ & $2.05 \pm 0.67$ & $15.6 \pm 4.6$ & $21.5 \pm 2.54$ & $1.69 \pm 0.96$ & $1.36 \pm 0.38$ \\
\hline $\mathrm{NO}^{3}-\mathrm{N}(\mathrm{mg} / \mathrm{l})$ & $0.07 \pm 0.01$ & $0.12 \pm 0.02$ & $8.13 \pm 0.39$ & $10.9 \pm 0.84$ & $0.08 \pm 0.01$ & $0.08 \pm 0.03$ \\
\hline $\mathrm{HCO}_{3}{ }^{-}(\mathrm{mg} / \mathrm{l})$ & $4.26 \pm 0.97$ & $11.15 \pm 2.37$ & $48.08 \pm 5.68$ & $75.6 \pm 4.22$ & $4.81 \pm 2.64$ & $7.61 \pm 1.67$ \\
\hline $\begin{array}{l}\mathrm{FC}^{(\mathrm{cfu} / 100} \\
\mathrm{ml})\end{array}$ & $11.8 \pm 3.01$ & $14.4 \pm 2.63$ & $32500 \pm 8031$ & $54000 \pm 79801$ & $19.3 \pm 6.2$ & $13.7 \pm 2.1$ \\
\hline
\end{tabular}

\subsection{River upstream water characteristics}

The mean summary of physico-chemical and bacteriological results obtained from the analysis of Orogodo River are presented in Table 2. It was observed that among the physical parameters the water was colourless and odourless, while the temperature was slightly low (less than $30^{\circ} \mathrm{C}$ ) in all the locations during the sampling period.

Total suspended solids and turbidity was also observed to be low when compared to other Stations. pH was observed to be slightly acidic (5.73 \pm 0.44 and $6.59 \pm 0.25)$, while conductivity and TDS was low. These are characteristic of most lakes and streams of the world [30]-[32]. The nutrients load follows same pattern as observed in the conductivity and TDS as they were all low. Dissolved oxygen, BOD and COD were low indicating low oxygen demand on the water. Faecal coliform and total coliform bacteria were also recorded from this section of the river, though at a lower count compared to other Stations. The presence of faecal bacteria in this section of the river is due to open defecation practiced by some of the inhabitants of the area who do not have access to good waste facilities and organic material washed from the land into the river.

\subsection{River downstream water characteristics}

Downstream of the river after discharged effluent, there was observed changes in the colour and odour of the receiving river. The river water colour was greyish yellow, while the odour was still objectionable. The water temperature was slightly tepid $\left(>25^{\circ} \mathrm{C}\right)$ less than the 
wastewater temperature $\left(33.3 \pm 0.78^{\circ} \mathrm{C}\right)$. The $\mathrm{pH}$ was slightly acidic, while conductivity and TDS showed a significant drop in concentration when compared to the effluent concentrations. Oxygen demanding parameters and nutrients followed same pattern observed for TDS and conductivity. A gradual reduction in the physico-chemical load of the water as one move downstream of the river was observed in Stations these stations. Objectionable odours and colours were no longer observed in the stations and a drastic reduction in the TSS, temperature and turbidity were also indicated from the obtained results. Relatively low values were recorded for turbidity, BOD, COD, sulphate, nitrate and phosphates compared to the upstream river water.

\subsection{Comparison of obtained values to regulatory standards}

Comparison of mean data set for Orogodo River before and after effluent discharge and regulatory standards are shown in Table 3 . The $\mathrm{pH}$ of all the samples collected indicated slightly acidic environment. The $\mathrm{pH}$ range of this study is low comparable to $\mathrm{pH}$ ranges of 6.9-8.8 of previous studies on effluent from similar abattoirs in Nigeria [33], [34]. It is also slightly below most of the regulatory limits except Stations 3 and $4 . \mathrm{pH}$ is important to microorganisms because it affects the functioning of virtually all enzymes, hormones and proteins which control metabolism, growth and development.

Table 3: Comparison of the abattoir effluents with regulatory standards.

\begin{tabular}{|c|c|c|c|c|c|c|c|c|}
\hline Parameters & Station 1 & Station 2 & Station 3 & Station 4 & Station 5 & Station 6 & $\begin{array}{l}\text { FEPA } \\
(1991)\end{array}$ & $\begin{array}{l}\text { WHO } \\
\text { (2004) }\end{array}$ \\
\hline $\mathrm{pH}$ & 5.73 & 6.586 & 6.72 & 6.76 & 5.641 & 5.34 & 7 & $\begin{array}{c}6.5- \\
8.5 \\
\end{array}$ \\
\hline Temp $\left({ }^{\circ} \mathrm{C}\right)$ & 26.72 & 25.26 & 32.5 & 33.3 & 25.26 & 25.5 & $\begin{array}{c}<40^{\circ} \\
\mathrm{C}\end{array}$ & $24-30$ \\
\hline $\begin{array}{l}\text { Conductivity } \\
(\mu \mathrm{s} / \mathrm{cm})\end{array}$ & 72.8 & 74.54 & 780 & 841 & 85.693 & 74.783 & NS & 500 \\
\hline TDS (mg/l) & 65 & 69.32 & 677 & 750 & 77.94 & 67.44 & 2 & 0 \\
\hline $\mathrm{TSS}(\mathrm{mg} / \mathrm{l})$ & 14.6 & 16.47 & 185 & 227 & 15.81 & 15.21 & - & - \\
\hline $\mathrm{DO}(\mathrm{mg} / \mathrm{l})$ & 2.53 & 3.21 & 0.795 & 0.2 & 3.89 & 4.28 & $\begin{array}{c}<0.00 \\
7 \\
\end{array}$ & NS \\
\hline BOD (mg/l) & 11.8 & 11.27 & 95 & 113 & 7.83 & 6.87 & 50 & $>4.00$ \\
\hline COD (mg/l) & 78.6 & 88.7 & 964 & 1045 & 110.18 & 61.14 & $<75$ & 10 \\
\hline $\begin{array}{l}\text { Turbidity } \\
\text { (NTU) }\end{array}$ & 26.5 & 22.4 & 108 & 150 & 23.7 & 24.27 & NS & 40 \\
\hline $\begin{array}{l}\text { Phosphorus } \\
(\mathrm{mg} / \mathrm{l})\end{array}$ & 0.056 & 0.054 & 5.49 & 10.6 & 0.0366 & 0.0307 & 5 & NS \\
\hline $\mathrm{Cl}^{-}(\mathrm{mg} / \mathrm{l})$ & 0.623 & 3.554 & 46.8 & 49.3 & 0.9598 & 0.5466 & 600 & NS \\
\hline $\mathrm{SO}_{4}{ }^{2-}(\mathrm{mg} / \mathrm{l})$ & 1.937 & 2.053 & 15.6 & 21.5 & 1.6943 & 1.3643 & 500 & 250 \\
\hline $\begin{array}{l}\mathrm{NO}^{3}- \\
\mathrm{N}(\mathrm{mg} / \mathrm{l})\end{array}$ & 0.074 & 0.116 & 8.13 & 10.9 & 0.0782 & 0.0836 & 20 & 400 \\
\hline $\begin{array}{l}\mathrm{HCO}_{3}^{-} \\
(\mathrm{mg} / \mathrm{l})\end{array}$ & 4.26 & 11.15 & 48.08 & 75.6 & 4.814 & 7.608 & $<600$ & 45 \\
\hline $\begin{array}{l}\text { FC (cfu/100 } \\
\mathrm{ml})\end{array}$ & 11.8 & 14.4 & 32500 & 54000 & 19.3 & 13.7 & NS & NS \\
\hline
\end{tabular}


It is also a major factor in all chemical reactions associated with formation, alteration and dissolution of minerals. It was observed that most of the physic-chemical parameters analysed for the stations along the River course were outside the regulatory limits except Station 6 which has close to $80 \%$ compliance with most of the regulatory limits. These results may be due to the impact of the abattoir effluent discharges. This might have been as a result of the diluting and self-purification of the river as one move downstream.

\subsection{Seasonal comparison of the sampled locations}

Tables 4 and 5 showed the results from the seasonal variation of the physico-chemical parameters of Orogodo River and the discharged effluent load. Effects on the aesthetic of the effluents were the affected by the season as indicated by the objectionable odour and colour of the effluent discharges on the River. Other physical parameters like temperature, TSS and turbidity were higher in the dry season compared to the rainy season. This may be as a result of the diluting effect of rain and drainage water from the river catchment basin.

This also contributed to the observed higher conductivity and TDS in the dry season results. The diluting effects of the rain were also reflected in the concentrations of oxygen demanding parameters, nutrients and abundance level of faecal coliforms in the sampling stations. Generally, it was observed the physic-chemical load of the river and effluent was higher in the dry season compared to the rainy season.

Table 4: Orogodo River physico-chemical and bacteriological results (rainy season).

\begin{tabular}{|c|c|c|c|c|c|c|}
\hline Parameter & Station 1 & Station 2 & Station 3 & Station 4 & Station 5 & Station 6 \\
\hline $\mathrm{pH}$ & $5.43 \pm 0.9$ & $6.66 \pm 0.02$ & $6.75 \pm 0.0$ & $6.75 \pm 0.0$ & $5.81 \pm 0.45$ & $5.71 \pm 0.66$ \\
\hline Temp $\left({ }^{\circ} \mathrm{C}\right)$ & $24.80 \pm 0.0$ & $25.80 \pm 2.53$ & $32.50 \pm 0.0$ & $33.40 \pm 0.0$ & $25.72 \pm 2.35$ & $26.20 \pm 2.50$ \\
\hline $\begin{array}{l}\text { Conductivity } \\
(\mu \mathrm{s} / \mathrm{cm})\end{array}$ & $68.40 \pm 0.0$ & $73.13 \pm 3.92$ & $750.00 \pm 0.0$ & $825.0 \pm 0.0$ & $80.99 \pm 4.73$ & $72.07 \pm 4.05$ \\
\hline TDS (mg/l) & $62.40 \pm 0.0$ & $69.60 \pm 4.45$ & $670.00 \pm 0.0$ & $750.0 \pm 0.0$ & $73.28 \pm 4.58$ & $66.08 \pm 3.80$ \\
\hline TSS (mg/l) & $12.20 \pm 0.0$ & $17.70 \pm 3.92$ & $180.00 \pm 0.0$ & $220.0 \pm 0.0$ & $16.02 \pm 1.51$ & $16.02 \pm 2.24$ \\
\hline DO (mg/l) & $2.30 \pm 0.0$ & $3.28 \pm 0.10$ & $0.88 \pm 0.0$ & $0.20 \pm 0.0$ & $3.66 \pm 0.67$ & $4.06 \pm 0.46$ \\
\hline BOD (mg/l) & $10.50 \pm 0.0$ & $11.40 \pm 0.80$ & $95.50 \pm 0.0$ & $110.5 \pm 0.0$ & $8.66 \pm 2.50$ & $7.24 \pm 1.79$ \\
\hline COD (mg/l) & $77.90 \pm 0.0$ & $90.50 \pm 4.27$ & $960.00 \pm 0.0$ & $1025 \pm 0.0$ & $\begin{array}{c}102.66 \pm 15 \\
8\end{array}$ & $64.78 \pm 13.0$ \\
\hline $\begin{array}{l}\text { Turbidity } \\
\text { (N.T.U) }\end{array}$ & $23.80 \pm 0.0$ & $22.20 \pm 0.49$ & $105.00 \pm 0.0$ & $150.0 \pm 0.0$ & $23.40 \pm 1.50$ & $23.44 \pm 1.68$ \\
\hline $\begin{array}{l}\text { T.Phosphorus } \\
(\mathrm{mg} / \mathrm{l})\end{array}$ & $0.02 \pm 0.0$ & $0.05 \pm 0.02$ & $5.50 \pm 0.0$ & $10.30 \pm 0.0$ & $0.05 \pm 0.04$ & $0.04 \pm 0.01$ \\
\hline $\mathrm{Cl}^{-}(\mathrm{mg} / \mathrm{l})$ & $0.58 \pm 0.0$ & $3.89 \pm 0.57$ & $45.50 \pm 0.0$ & $49.10 \pm 0.0$ & $1.30 \pm 1.28$ & $0.96 \pm 1.45$ \\
\hline $\mathrm{SO}_{4}^{2-}(\mathrm{mg} / \mathrm{l})$ & $1.14 \pm 0.0$ & $2.31 \pm 0.80$ & $14.00 \pm 0.0$ & $20.50 \pm 0.0$ & $2.05 \pm 1.11$ & $1.59 \pm 0.40$ \\
\hline $\mathrm{NO}^{3}-\mathrm{N}(\mathrm{mg} / \mathrm{l})$ & $0.07 \pm 0.0$ & $0.13 \pm 0.01$ & $8.15 \pm 0.0$ & $10.50 \pm 0.0$ & $0.08 \pm 0.02$ & $0.10 \pm 0.40$ \\
\hline $\mathrm{HCO}_{3}^{-}(\mathrm{mg} / \mathrm{l})$ & $3.66 \pm 0.0$ & $11.60 \pm 0.80$ & $47.08 \pm 0.0$ & $77.60 \pm 0.0$ & $5.77 \pm 3.25$ & $7.90 \pm 2.20$ \\
\hline $\begin{array}{ll}\mathrm{FC} & (\mathrm{cfu} / 100 \\
\mathrm{ml}) & \end{array}$ & $10.00 \pm 0.0$ & $13.80 \pm 3.43$ & $32000 \pm 4000$ & $\begin{array}{c}25400 \pm 320 \\
0\end{array}$ & $16.20 \pm 5.98$ & $13.40 \pm 1.96$ \\
\hline
\end{tabular}


Table 5: Orogodo River physico-chemical and bacteriological results (dry season).

\begin{tabular}{|c|c|c|c|c|c|c|}
\hline Parameter & Station 1 & Station 2 & Station 3 & Station 4 & Station 5 & Station 6 \\
\hline $\mathrm{pH}$ & $6.47 \pm 0.85$ & $6.87 \pm 0.69$ & $7.24 \pm 1.09$ & $6.81 \pm 0.09$ & $5.47 \pm 0.0$ & $5.81 \pm 1.41$ \\
\hline Temp $\left({ }^{\circ} \mathrm{C}\right)$ & $31.10 \pm 4.84$ & $26.8 \pm 4.05$ & $33.72 \pm 2.41$ & $34.30 \pm 2.15$ & $27.04 \pm 4.4$ & $24.80 \pm 0.0$ \\
\hline $\begin{array}{l}\text { Conductivity } \\
(\mu \mathrm{s} / \mathrm{cm})\end{array}$ & $84.76 \pm 14.8$ & $77.32 \pm 2.7$ & $864.77 \pm 107$ & $903.04 \pm 90.5$ & $94.87 \pm 8.8$ & $77.50 \pm 0.0$ \\
\hline TDS (mg/l) & $72.62 \pm 9.87$ & $70.92 \pm 3.69$ & $761.33 \pm 151$ & $820.71 \pm 139$ & $91.5 \pm 17.6$ & $68.80 \pm 0.0$ \\
\hline TSS (mg/l) & $21.82 \pm 9.47$ & $15.82 \pm 1.14$ & $207.32 \pm 34.1$ & $272.44 \pm 74.8$ & $16.1 \pm 0.88$ & $14.40 \pm 0.0$ \\
\hline $\mathrm{DO}(\mathrm{mg} / \mathrm{l})$ & $3.22 \pm 0.90$ & $3.50 \pm 0.70$ & $1.02 \pm 0.62$ & $0.21 \pm 0.03$ & $4.30 \pm 0.35$ & $4.50 \pm 0.0$ \\
\hline $\mathrm{BOD}(\mathrm{mg} / \mathrm{l})$ & $15.05 \pm 3.83$ & $11.90 \pm 1.49$ & $101.9 \pm 214.5$ & $120 \pm 10.7$ & $7.45 \pm 0.88$ & $6.50 \pm 0.0$ \\
\hline $\mathrm{COD}(\mathrm{mg} / \mathrm{l})$ & $84.71 \pm 10.6$ & $91.37 \pm 8.79$ & $978.95 \pm 21.5$ & $1119.8 \pm 107$ & $118 \pm 0.88$ & $57.50 \pm 0.0$ \\
\hline $\begin{array}{l}\text { Turbidity } \\
\text { (N.T.U) }\end{array}$ & $37.43 \pm 16.2$ & $24.39 \pm 3.52$ & $116.48 \pm 10.7$ & $157.1 \pm 13.9$ & $24.5 \pm 0.88$ & $25.10 \pm 0.0$ \\
\hline $\begin{array}{l}\text { T.Phosphorus } \\
(\mathrm{mg} / \mathrm{l})\end{array}$ & $0.14 \pm 0.09$ & $0.09 \pm 0.07$ & $5.73 \pm 0.49$ & $11.67 \pm 1.70$ & $0.03 \pm 0.02$ & $0.02 \pm 0.0$ \\
\hline $\mathrm{Cl}^{-}(\mathrm{mg} / \mathrm{l})$ & $0.75 \pm 0.16$ & $4.63 \pm 2.79$ & $52.44 \pm 8.53$ & $51.02 \pm 2.98$ & $0.71 \pm 0.18$ & $0.14 \pm 0.0$ \\
\hline $\mathrm{SO}_{4}^{2-}(\mathrm{mg} / \mathrm{l})$ & $4.08 \pm 2.64$ & $1.99 \pm 0.38$ & $23.62 \pm 12.6$ & $25.96 \pm 6.81$ & $1.78 \pm 0.88$ & $1.14 \pm 0.0$ \\
\hline $\mathrm{NO}^{3}-\mathrm{N}(\mathrm{mg} / \mathrm{l})$ & $0.08 \pm 0.01$ & $0.12 \pm 0.03$ & $8.69 \pm 1.13$ & $12.40 \pm 2.15$ & $0.08 \pm 0.01$ & $0.07 \pm 0.0$ \\
\hline $\mathrm{HCO}_{3}^{-}(\mathrm{mg} / \mathrm{l})$ & $5.96 \pm 2.15$ & $14.06 \pm 6.63$ & $57.45 \pm 16.4$ & $79.08 \pm 10.7$ & $4.31 \pm 0.88$ & $7.32 \pm 0.0$ \\
\hline $\begin{array}{l}\mathrm{FC} \mathrm{(cfu/100} \\
\mathrm{ml})\end{array}$ & $17.1 \pm 6.90$ & $15.00 \pm 0.0$ & $\begin{array}{c}44157 \pm 2194 \\
0 \\
\end{array}$ & $\begin{array}{c}193373 \pm 217 \\
823 \\
\end{array}$ & $26.5 \pm 8.53$ & $16.24 \pm 4.4$ \\
\hline
\end{tabular}

\section{CONCLUSION AND RECOMMENDATIONS}

The effects of abattoir wastewater discharge into Orogodo River on its water quality were assessed through water quality monitoring. Findings from the study indicate that livestock processing and activities around the Abattoir have impacted the river water quality. Concentrations of oxygen demanding parameters, nutrients and faecal coliforms were in excess of normal levels for the river water. The downstream levels of these parameters were higher than their corresponding upstream values, indicating that the discharge of the abattoir wastewater into the river has negatively impacted water. The dilution of the high-strength abattoir wastewater in the river water was not enough to reduce most of the physico-chemical parameters and bacterial load to acceptable levels. Although there is a potential that an improvement of the water quality may be observed further downstream due to self-purification and further dilution effects, the high levels of these parameters is a worrying issue to the riparian users around the abattoir.

This water quality data and pollution source information will be useful in identifying water quality intervention measures. The findings can also be used as basis for strengthening existing legislation.

\section{REFERENCES}

[1] Alonge, D.O., Textbook of Meat Hygiene in the Tropics, Farmcoe Press: Ibadan, pp. 98-105, 1991.

[2] Nafaranda, W.D., Yaji, A. \& Icubkomawa, H.I., Impact of abattoir wastes on aquatic life. Global Journal of Pure and Applied Sciences, 12(1), pp. 31-33, 2005.

[3] Asibor, G., Edjere, O. \& Ofejiro, P., Physico-chemical and bacteriological assessment of abattoir effluents and its effects on Agbarho River, Delta State Nigeria. Nigerian Journal of Applied Science, 35, pp. 265-276, 2017.

[4] Mittal, G.S., Treatment of wastewater from abattoir before land-application - a review. Bioresource Technology, 97, pp. 1119-1135, 2006. 
[5] Adeyemi-Ale, O.A., Impact of abattoir effluent on the physico-chemical parameters of Gbagi Stream (Odo-Eran), Ibadan, Nigeria. Ilorin Journal of Science, 1(1), pp. 100109, 2014.

[6] Raymond, C.L., Pollution Control for Agriculture, Academic Press Inc.: New York, 1977.

[7] Cooper, R.N., Hoodle, J.R. \& Russel, J.M., Characteristics and treatment of slaughterhouse effluent in New Zealand. Prog Water Technology, 11, pp 55-68, 1979.

[8] Quinn, J.M. \& McFarlane, P.N., Effects of slaughterhouse and dairy factory wastewaters on epilithon: A comparison in laboratory streams. Water Research, 23(10), pp. 1267-1273, 1989.

[9] Sangodoyin, A.Y. \& Agbawhe O.M., Environmental study on surface and groundwater pollutants from abattoir effluents. Bioresource Technology, 41(2), pp. 193-200, 1992.

[10] Omole, D.O. \& Longe, E.O., An assessment of the impact of abattoir effluents on River Illo, Ota, Nigeria. Journal of Environmental Science and Technology, 1(2), pp. 56-54, 2008.

[11] Akpor, O.B. \& Muchie, M., Environmental and public health implications of wastewater quality. African Journal of Biotechnology, 10(13), pp. 2379-2387, 2011.

[12] Ezeoha, S.L. \& Ugwuishiwu, B.O., Status of Abattoir Wastes Research in Nigeria. Nigerian Journal of Technology. 30(2), pp. 143-148, 2011.

[13] Adelegan, J.A., Environmental policy and slaughterhouse waste in Nigeria. Proceedings of the 28th WEDC Conference, Calcutta, India, pp. 3-6, 2002.

[14] Ojo, J.O., Environmental impact assessment of effluents from Oko-Oba municipal abattoir at Agege, Lagos State, Nigeria. Global Advanced Research Journal of Agricultural Science, 3(10), pp. 317-320, 2014.

[15] Ogbonna, D.N. \& Ideriah, T.J.K., Effect of abattoir wastewater on physico-chemical characteristics of soil and sediment in southern, Nigeria. Journal of Scientific Research and Reports, 3(12), pp. 1612-1632, 2014.

[16] Omole, D.O. \& Ogbiye, A.S., An evaluation of slaughterhouse wastes in south-west Nigeria. American Journal of Environmental Protection, 2(3), pp. 85-89, 2013.

[17] Adeyemo, O.K., Ayodeji, I.O. \& Aiki-Raji, C.O., The water quality and sanitary conditions in a major abattoir (Bodija) in Ibadan, Nigeria. African Journal of Biomedical Research, 5, pp. 51-55, 2002.

[18] Edjere, O. \& Iyekowa, O., Assessment of the levels of polychlorinated biphenyls (PCBs) in Orogodo River sediments Agbor, Delta State, Nigeria. Ovidius University Annals of Chemistry, 28(2), pp. 25-29, 2017. https://doi.org/10.1515/auoc-2017-0005.

[19] Ademoroti, C.M.O., Standard Methods for Water and Effluents Analysis, Foludex Press Ltd.: Ibadan, pp. 58-76, 1996.

[20] APHA, AWWA \& WEF, Standard Methods for the Examination of Water and Wastewater. 20th ed., American Public Health Association, American Water Works Association and Water Environment Federation: Washington DC., 1999.

[21] Padilla-Gasca, E., Lopez-Lopez, A. \& Gallardo-Vaidez, J., Evaluation of stability factor in the anaerobic treatment of slaughterhouse wastewater. Journal of Bioremediation and Biodegradation, 2, pp. 114-124, 2011.

[22] Kwadzah, T.K. \& Iorhemen, O.T., Assessment of the impact of abattoir effluent on the water quality of River Kaduna, Nigeria. World Journal of Environmental Engineering, 3(3), pp 87-94, 2015. 
[23] Ogbomida, E.T., Kubeyinje, B. \& Ezemonye, L.I., Evaluation of bacterial profile and biodegradation potential of abattoir wastewater. African Journal of Environmental Science and Technology, 10(2), pp. 50-57, 2016.

[24] Mulu, A., Ayenew, T. \& Berhe, S., Impact of Slaughterhouses Effluent on Water Quality of Modjo and Akaki River in Central Ethiopia. International Journal of Science and Research, 4(3), pp. 899-907, 2013.

[25] Kolawole, O.M., Ajayi, K.T., Olayemi, A.B. \& Okoh, A.I., Assessment of water quality in Asa River (Nigeria) and its indigenous Clarias gariepinus fish. International Journal of Environmental Research and Public Health, 8(11), pp. 4332-4352, 2011.

[26] Ogedengbe, O., Technologies for Industrial waste Management. Paper for a short certificate course workshop on Environmentally Friendly Technologies for Management of Waste, Institute of Ecology and Environmental Studies and the UNICECS, O.A.U. Ile-Ife, Nigeria, 1990.

[27] Mara, D.D., Wastewater treatment in hot climates. Water, Wastes and Health in Hot Climates, eds R. Feacham, M. McGarry \& D.D. Mara, John Wiley and Sons: New York, 1977.

[28] Chapman, D., Water Quality Assessments: A Guide to the Use of Biota, Sediment and Water in Environmental Monitoring, 2nd ed., E and FN Spon: London, pp. 626, 1996.

[29] Practi, L., Pavenello, R. \& Pasarin, P., Assessment of surface water quality by a single index of pollution. Water Research, 5, pp. 741-751, 1971.

[30] Akinbuwa, O., The Rotifera fauna and physico-chemical conditions of Erinle lake and its major inflows at Ede, Osun State, Nigeria. PhD thesis, Obafemi Awolowo University, 1999.

[31] Akande, A.O. \& Awotoye, O., Some aspects of the ecology of Isiula Lake - a natural aquatic ecosystem in Ado-Ekiti, Nigeria. Nigerian Journal of Botany, 3, pp. 221-230, 1990.

[32] Ekpeyong, E. \& Adeniyi, I.F., Physical and chemical factors and net phytoplankton distribution in some tropical fishponds. Tropical Freshwater Biology, 5, pp. 43-53, 1996.

[33] Osibanjo, O. \& Adie, G.U., The impact of effluent from Bodija abattoir on the physicochemical parameters of Oshunkeye stream in Ibadan City, Nigeria. African Journal of Biotechnology, 6(15), pp. 1806-1811, 2007.

[34] Raheem, N.K. \& Morenikeji, O.A., Impact of abattoir effluents on surface waters of the Alamuyo stream in Ibadan. Journal of Applied Sciences and Environmental Management, 12(1), pp. 73-77, 2018. 